\title{
Generation of genetic recombinants in Trichosporon cutaneum by spontaneous segregation of protoplast fusants
}

\author{
Marzena Sieńko, ${ }^{1}$ Piotr P. StęPień ${ }^{2}$ and Andrzej Paszewski ${ }^{1 *}$ \\ ${ }^{1}$ Institute of Biochemistry and Biophysics, Polish Academy of Sciences, Rakowiecka 36, 02-532 Warsaw, Poland \\ ${ }^{2}$ Department of Genetics, Warsaw University, al. Ujazdowskie 4, 00-478 Warsaw, Poland
}

(Received 3 December 1991; revised 30 March 1992; accepted 3 April 1992)

\begin{abstract}
Auxotrophic mutants were isolated in two strains of Trichosporon cutaneum. Complementing auxotrophs were hybridized by protoplast fusion. Some of the fusants were apparently transient diploids and segregated to give recombinant marker combinations.
\end{abstract}

\section{Introduction}

The soil yeast Trichosporon cutaneum is very versatile in metabolizing various organic components. It has been shown to grow on various disaccharides (Mörtberg \& Neujahr, 1986), xylans, cellulose (Hrmova et al., 1984) and starch (De Mot et al., 1984). In addition, T. cutaneum is able to metabolize phenol and other aromatic compounds (Gaal \& Neujahr, 1979; Anderson \& Dagley, 1980), and it gives high biomass yield (Petkov et al., 1984; Fiechter et al., 1987). These properties make $T$. cutaneum an interesting candidate for conversion of various carbon sources to biomass (Glumoff et al., 1989).

Genetical studies depend on the availability of suitable mutants. Leucine-requiring mutants were isolated in T. cutaneum by Stępień et al. (1988), and successful genetic transformation and gene cloning have been described recently (Glumoff et al., 1989; Ochsner et al., 1991). Isolation of a variety of auxotrophic mutants in Trichosporon adeninovorans has also been reported (Samsonova et al., 1989).

Here we describe the isolation of auxotrophic mutants and protoplast fusion in two strains of $T$. cutaneum. The data show the formation of transitional diploids which segregate spontaneously, often producing progeny with a nonparental combination of markers.

\section{Methods}

Strains, media and culture conditions. Two prototrophic strains of Trichosporon cutaneum, both isolated from nature, were used in this study: Trl, from the collection of Lódź Technical University (Poland), and UCD 54-169, from the Industrial Yeast Collection (Perugia, Itály).

* Author for correspondence. Tel. 4809 75; fax (48) 39121623.
Cells were grown in a rotary shaker $(150$ r.p.m. $)$ at $30^{\circ} \mathrm{C}$. For standard cultures, yeast extract $(1 \%)$, Bacto-peptone $(2 \%)$ and glucose $(2 \%)$ (YPG) was used as a complete medium and the glucose-mineral salt medium of Galzy \& Słonimski (1957) as minimal medium (Go). The latter was supplemented when necessary with amino acids at a concentration of $30 \mu \mathrm{g} \mathrm{ml}^{-1}$, and with adenine and uracil at a concentration of $20 \mu \mathrm{g} \mathrm{ml}^{-1}$.

Mutagenesis. Cells from the exponential phase of growth $\left(2 \times 10^{7}\right.$ cells $\mathrm{ml}^{-1}$ ) were centrifuged at $3000 \mathrm{~g}$ for $10 \mathrm{~min}$ at $20^{\circ} \mathrm{C}$, washed with $0.9 \% \mathrm{NaCl}$ and resuspended in $5 \mathrm{ml}$ sodium citrate buffer, pH 5.5. Mutants were obtained after mutagenesis with MNNG ( $N$-methyl- $N^{\prime}$ nitro- $N$-nitrosoguanidine) at a concentration of $0.5 \mathrm{mg} \mathrm{ml}^{-1}$ for $30 \mathrm{~min}$. The mutagen was removed by washing twice with $0.9 \% \mathrm{NaCl}$. The survival rate was $10-20 \%$ and $1-10 \%$ for strains $\operatorname{Tr} 1$ and UCD 54-169, respectively. After plating on complete medium and screening on minimal medium auxotrophs were isolated and their requirements determined.

Protoplast formation. The formation of protoplasts was achieved using Novozym 234 (Hamlyn et al., 1981). The cells were grown to midexponential phase $\left(1 \times 10^{7}\right.$ cells $\left.\mathrm{ml}^{-1}\right)$ in YPG medium. They were collected by centrifugation at $3000 \mathrm{~g}$ for $10 \mathrm{~min}$ at $20^{\circ} \mathrm{C}$ and resuspended in $5 \mathrm{ml}$ buffer $\mathrm{A}(0.01 \mathrm{M}$-potassium phosphate $\mathrm{pH} 6.0$ containing $0.6 \mathrm{M}-\mathrm{KCl})$. Novozym was added $\left(5 \mathrm{mg} \mathrm{m}^{-1}\right)$ and the cell suspension was incubated at $30^{\circ} \mathrm{C}$ for $1 \mathrm{~h}$ with gentle shaking. Protoplast formation was monitored microscopically and confirmed by measuring the $\mathrm{OD}_{600}$ of the cell suspension before and after the addition of SDS to a final concentration of $1 \%$. The protoplasts were centrifuged at $1000 \mathrm{~g}$ for $5 \mathrm{~min}$ at $20^{\circ} \mathrm{C}$ and washed twice with $5 \mathrm{ml}$ buffer B (0.05 $\mathrm{M}$-Tris/ $\left.\mathrm{HCl} \mathrm{pH} 7.5,0.01 \mathrm{M}-\mathrm{CaCl}_{2}, 0.6 \mathrm{M}-\mathrm{KCl}\right)$.

Protoplast fusion. For fusion, equal numbers of protoplasts from each strain were suspended in the same volume of buffer B. Portions $(0.1 \mathrm{ml})$ of each suspension were mixed $\left(10^{7}\right.$ cells $\left.\mathrm{ml}^{-1}\right)$ and $1 \mathrm{ml}$ PEG solution $\left(40 \%\right.$ PEG $\left.4000,0 \cdot 1 \mathrm{M}-\mathrm{CaCl}_{2}\right)$ was added. The mixture was incubated at $30^{\circ} \mathrm{C}$ for $30 \mathrm{~min}$, diluted with $3 \mathrm{ml}$ buffer $A$, mixed with $4 \mathrm{ml}$ top agar (Go medium, $0.6 \mathrm{M}-\mathrm{KCl}, 2 \%, \mathrm{w} / \mathrm{v}$, agar) warmed to $50^{\circ} \mathrm{C}$, supplemented with amino acids when necessary, and poured onto minimal plates stabilized with $0.6 \mathrm{M}-\mathrm{KCl}$. The plates were incubated at $30^{\circ} \mathrm{C}$ for 4-6 d and the fusion hybrid colonies were replicated on Go and YPG. Those growing only on YPG were suspended in $0.9 \% \mathrm{NaCl}$ 
and plated on YPG for single-cell colonies. Their phenotype was determined by replica-plating on selective medium.

The regeneration rate was determined by plating protoplasts into top agar supplemented appropriately with nutritional requirements.

\section{Results and Discussion}

\section{Isolation of autrophic mutants}

Only leucine-requiring auxotrophic mutants (11 among approximately 20000 colonies tested) were obtained in strain $\operatorname{Tr} 1$. This confirms our previous results (Stępień et al., 1988), when after many rounds of mutagenesis only leucine auxotrophs were obtained. The appearance of only one class of auxotrophic mutants, which were recessive, as found in fusants (see below), indicates that this strain is not haploid; it may be aneuploid or, more probably, have one mutated or nonfunctional copy of a gene involved in leucine biosynthesis. In contrast, in strain UCD 54-169 a variety of auxotrophic mutants was readily selected, suggesting that this strain is haploid. Among approximately 500 colonies tested which survived mutagenesis, 16 auxotrophs with the following requirements were found: histidine (5), arginine (4),

Table 1. Trichosporon cutaneum strains used for fusion

\begin{tabular}{lll}
\hline \hline Strain & \multicolumn{1}{c}{ Origin } & Phenotype \\
\hline M20 & Tr1 & Leu- \\
U6 & UCD 54-169 & Trp \\
U7 & UCD 54-169 & His \\
U22 & UCD 54-169 & His $^{-}$ \\
U25 & UCD 54-169 & Arg- \\
U7-1 & U7 & His Ura- $^{-}$ \\
U25-2 & U25 & Arg-Met $^{-}$ \\
U25-11 & U25 & Arg- Ade $^{-}$ \\
\hline \hline
\end{tabular}

lysine (2), adenine (1), methionine (1), tryptophan (1), isoleucine + valine (1) and uracil (1).

The frequency of mutants among surviving cells was $2 \times 10^{-4}$ and $320 \times 10^{-4}$ for strains Trl and UCD 54-169, respectively. All the mutations had a reversion frequency of $\left\langle 10^{-7}\right.$. Several auxotrophs were further mutagenized and double auxotrophic mutants were obtained. These mutants and their derivatives are listed in Table 1. They were used for fusion experiments.

\section{Fusion of protoplasts of auxotrophic strains}

In all the experiments the frequency of fusion resulting in colonies growing on selective medium was about 0.5 $1 \times 10^{-3}$, which is similar to the results described for Candida sp. N-16 (Fujii et al., 1988). No colonies appeared on the control plates. Regeneration was 40$60 \%$.

All colonies selected on minimal medium (or minimal medium with supplements required by both strains) were stable prototrophs (or carried common markers) even after four passages through the non-selective (YPG) medium.

\section{Fusion between strains $\operatorname{Tr} 1$ and UCD 54-169}

When mutants derived from strains $\operatorname{Tr} 1$ and UCD 54169 were fused, the resulting prototrophic colonies showed the pattern of carbon source utilization characteristic of Trl or a new phenotype: i.e. no growth on rhamnose, sucrose and sorbose (Table 2). It appears, therefore, that the majority of selected colonies simply represent strain $\operatorname{Tr} 1$ which has acquired the wild-type copy of the leu gene. The fact that these two strains fuse readily indicates their compatibility in spite of the differences in growth on disaccharides, response to

Table 2. Fusion of auxotrophic mutants

\begin{tabular}{|c|c|c|c|c|c|c|}
\hline \multirow[b]{2}{*}{ Strains } & \multirow{2}{*}{$\begin{array}{c}\text { No. of } \\
\text { hybrids from } \\
10^{7} \text { protoplasts }\end{array}$} & \multirow{2}{*}{$\begin{array}{l}\text { No. of } \\
\text { colonies } \\
\text { examined }\end{array}$} & \multicolumn{4}{|c|}{$\begin{array}{l}\text { Growth of the fusants on } \\
\text { different disaccharides* }\end{array}$} \\
\hline & & & Lactose & Rhamnose & Sucrose & Sorbose \\
\hline \multicolumn{7}{|l|}{ Parental } \\
\hline UCD 54-169 & - & - & + & - & + & + \\
\hline $\operatorname{Trl}$ & - & - & + & + & + & - \\
\hline \multicolumn{7}{|l|}{ Fusants } \\
\hline $\mathrm{U} 22 \times \mathrm{U} 25$ & 42 & 20 & + & - & + & + \\
\hline $\mathrm{U} 6 \times \mathrm{U} 25$ & 120 & 50 & + & - & + & + \\
\hline $\mathrm{U} 25-11 \times \mathrm{U} 25-2$ & 166 & 50 & + & - & + & + \\
\hline \multirow[t]{2}{*}{$\mathrm{M} 20 \times \mathrm{U} 25$} & 87 & 26 & + & + & + & - \\
\hline & & 4 & + & - & - & - \\
\hline \multirow[t]{2}{*}{$\mathrm{M} 20 \times \mathrm{U} 25-2$} & 79 & 23 & + & + & + & - \\
\hline & & 7 & + & - & - & - \\
\hline
\end{tabular}

$*+$, Growth; -, no growth. 
Table 3. Marker segregation in hybrids

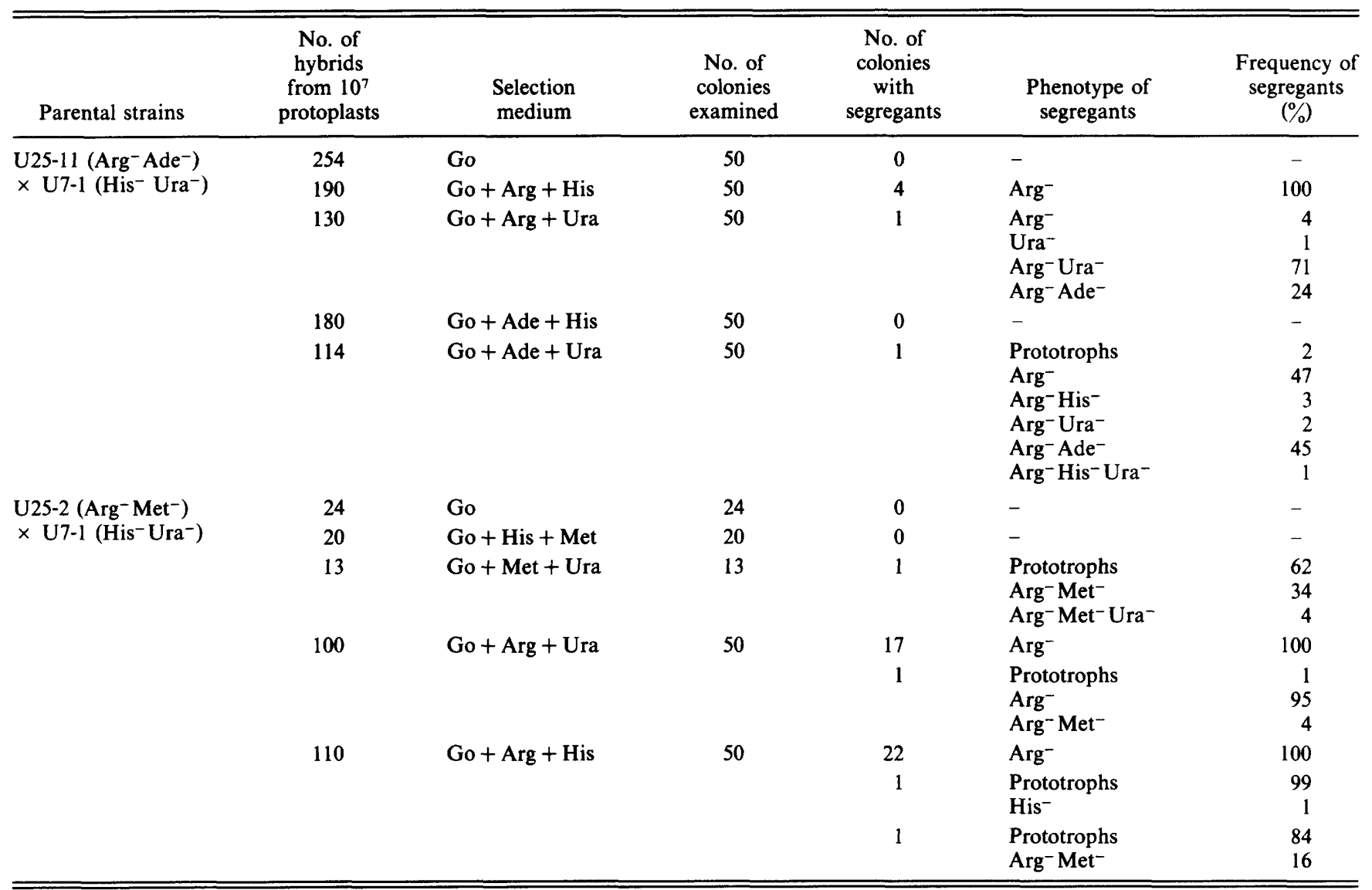

mutagenic treatment and, most probably, differences in chromosome sets. Precise determination of DNA content per cell was not feasible, as the strains of $T$. cutaneum we used produce a large proportion of biomass in the form of filaments of variable lengths.

\section{Fusion between mutants derived from strain UCD 54-169}

When fusion within UCD-derived mutants was carried out, all colonies selected on minimal medium were also stable prototrophs.

Different results were observed, however, when the preliminary selection was done on partially selective medium which lacked one of the supplements necessary for growth of parental strains. Colonies which were grown on such plates after fusion appeared homogeneous (no sectors were observed). They were then replicated on Go and YPG medium. Those colonies which after passage grew on YPG medium only were suspended in $0.9 \% \mathrm{NaCl}$ and plated on YPG medium for single-cell colonies. The resulting colonies were replicated on selective media to determine their phenotype.
It is clear from the results shown in Table 3 that the primary colonies were composed of cells showing both parental and recombinant phenotypes. Phenotypes of segregants were stable during four successive passages through the non-selective medium. A few auxotrophic segregants were further mutagenized and new auxotrophic mutations were obtained in them, which strongly suggests that these segregants were haploid or aneuploid.

It is worth noting that only one parental type ( $\mathrm{Arg}^{-} \mathrm{Ade}^{-}$and $\mathrm{Arg}^{-} \mathrm{Met}^{-}$) was observed in the progeny of fusants in each combination tested and that segregation of auxotrophic markers showed various patterns for different fusants. In addition, many segregants with nonsupplemented requirements were obtained in these experiments, with a strong preponderance of arginine auxotrophs. These segregants survived the whole screening procedure, possibly due to the accumulation of arginine in cells. It is known, for instance, that Saccharomyces cerevisiae and Neurospora crassa accumulate large amounts of arginine in vacuoles (Messenguy $e t$ al., 1980; Subramanian et al., 1973).

The results presented here indicate that naturally 
occurring T. cutaneum strains differ in ploidy but in spite of this they fuse readily. At least in a proportion of fusants karyogamy takes place and the resulting nuclei are unstable, spontaneously segregating out both parental and recombinant progeny (due to chromosome segregation and possibly mitotic crossing-over). The fact that nuclear fusion occurs readily provides an opportunity of obtaining strains with desired marker combinations. Together with transformation and cloning techniques (Glumoff et al., 1990; Ochsner et al., 1991) it creates a basis for efficient genetic manipulation in $T$. cutaneum, in spite of the lack of sexual reproduction in this organism.

We are greatly indebted to Professor A. Martini for Trichosporon cutaneum strain UCD 54-169.

\section{References}

ANDERson, J. J. \& DAGLEY, S. (1980). Catabolism of aromatic acids in Trichosporon cutaneum. Journal of Bacteriology 141, 534-543.

De Mot, R., Demeersman, H. \& Verachtert, H. (1984). Comparative study of starch degradation and amylase production by nonascomycetous yeast species. Systematic and Applied Microbiology 5, 421-432.

FIECHTER, A., KäPPELI, O. \& MEussDOERFFER, F. (1987). Batch and continous culture. In The Yeasts, vol, 2, pp. 99-129. Edited by A. H. Rose \& J. S. Harrison. London: Academic Press.

Fuji, T., Takenaka, E., Fujinami, K., ANDO, A.\& Yabuki, M. (1988). Intraspecific hybridization of a methanol-utilizing yeast, Candida sp. N-16, through protoplast fusion. Agricultural and Biological Chemistry 52, 1675-1682.

GaAl, A. \& Neujahr, N. Y. (1979). Metabolism of phenol and resorcinol in Trichosporon cutaneum. Journal of Bacteriology 137, 1321.
Galzy, P. \& SŁonimski, P. P. (1957). Chimie biologique - variations physiologiques de la levure au cours de la croissance sur l'acide lactique comme seule source de carbone. Comptes Rendus de l'Académie des Sciences, Paris 245, 2423-2426.

Glumoff, V., KÄPpelı, O., Fiechter, A. \& Reiser, J. (1989). Genetic transformation of filamentous yeast, Trichosporon cutaneum, using dominant selection markers. Gene 84, 311-318.

Glumoff, V., OChSNer, U., BÄrLOCher, K. \& Reiser, J. (1990). The yeast Trichosporon cutaneum as a host for heterologous gene expression. Yeast 6, S425.

Hamlyn, P. F., Bradshaw, R. E., Mellon, F. M., Santiago, C. M., WILsON, J. M. \& PEBERdY, J. F. (1981). Efficient protoplast isolation from fungi using commercial enzymes. Enzyme and Microbial Technology 3, 321-325.

Hrmova, M., Biely, P., Vrsanska, M. \& Petrakova, E. (1984). Induction of cellulose- and xylan-degrading enzyme complex in the yeast Trichosporon cutaneum. Archives of Microbiology 138, 371-376.

Messenguy, F., Colin, D. \& Ten Have, J. P. (1980). Regulation of compartmentation of amino acid pools in Saccharomyces cerevisiae and its effects on metabolic control. European Journal of Biochemistry 108, 439-447.

MÖRTBERG, M. \& NeUJAHR, H. Y. (1986). Transport and hydrolysis of disaccharides by Trichosporon cutaneum. Journal of Bacteriology 168, 734-738.

OChSNer, U., Glumoff, V., Kälin, M., Fiechter, A. \& Reiser, J. (1991). Genetic transformation of auxotrophic mutants of the filamentous yeast Trichosporon cutaneum using homologous and heterologous marker genes. Yeast 7, 513-524.

Petkov, P., Kostov, V., Balasheva, M. \& Bankov, I. (1984). The biosynthesis of protein and its amino acid content in strains of Trichosporon cutaneum cultured on nutrient media containing whey. Acta Microbiologica Bulgarica 14, 56-61.

Samsonova, I. A., Böttcher, F., Werner, C. \& Bode, R. (1989). Auxotrophic mutants of yeast Trichosporon adeninovorans. Journal of Basic Microbiology 29, 675-683.

Stepień, P. P., Sieńko, M. \& Pomorska, J. (1988). Genetics of Trichosporon cutaneum. Yeast 4, S256.

Subramanian, K. N., Weiss, R. L. \& Davis, R. H. (1973). Use of external, biosynthetic, and organellar arginine by Neurospora. Journal of Bacteriology 115, 284-290. 